\title{
Mycosis Fungoides and Sezary Syndrome N3 TNM Finding v8
}

National Cancer Institute

\section{Source}

National Cancer Institute. Mycosis Fungoides and Sezary Syndrome N3 TNM Finding v8.

NCl Thesaurus. Code C141320.

Clinically abnormal peripheral lymph nodes; histopathology Dutch grades 3-4 or NCI LN4; clone positive or negative. Note: EORT C N3 classification includes: Dutch grade 3: partial effacement of lymph node architecture; many atypical cerebriform mononuclear cells. Dutch grade 4: complete effacement of lymph node. NCI LN4: partial/complete effacement of nodal architecture by atypical lymphocytes or frankly neoplastic cells.

(from AJCC 8th Ed.) 